UDC 37.015.3 (045)

DOI https://doi.org/10.24919/2308-4863/34-3-30

Viktoriia ZINCHENKO, orcid.org/0000-0003-3080-4272

Candidate of Pedagogical Sciences,

Associate Professor at the Department of Foreign Philology,

Ukrainian Studies and Social and Law Disciplines

Donetsk National University of Economics and Trade named after Mikhailo Tugan-Baranovsky

(Kriviy Rig, Dnipropetrovsk region, Ukraine) zinchenko@donnuet.edu.ua

Svitlana REVUTSKA, orcid.org/0000-0002-8969-1295

Candidate of Philological Sciences,

Associate Professor at the Department of Foreign Philology,

Ukrainian Studies and Social and Law Disciplines

Donetsk National University of Economics and Trade named after Mikhailo Tugan-Baranovsky

(Kriviy Rig, Dnipropetrovsk region, Ukraine) revutska@donnuet.edu.ua

\title{
CREATIVITY AS A PSYCHOLOGICAL MEANS OF PEDAGOGICAL CREATIVENESS
}

The article deals with creativity as a psychological means of pedagogical creativeness. This paper states that future teachers of technical subjects should reasonably consider not only isolated technical or pedagogical creativeness development, but also their organic integration as the bases of teacher training skill formation, to some extent characterized by creativity. The creativity term is defied as well as determined with divergent and convergent thinking. This research focuses on the fact that convergent thinking is the kind of thinking usually associated with problem solving or intelligent skills. Additional definition of convergent thinking represents solving any other type of problem referred to get a right answer. This term is opposed with divergent thinking, when a person develops a new and original way of thinking that may contain a number of possible problem solutions. This paper describes the key basic characteristics of creativity, in particular the speed, originality, flexibility, sensitivity, metaphoricity etc. Moreover this article analyzes the interrelation of intelligent skills and creativity. Certain permissible level of intelligence corresponds to any profession. Individuals who have IQ below this level can not master a particular profession. If intelligent skills are higher than the lowest permissible level, there is no direct correlation between intelligence and achievements. A high level of intelligence causes the higher levels of creative abilities and vice versa. People who have high intelligent skills and low creativity are the victims of the traditional education system aimed to provide students with the maximum of ready made knowledge. The development of student creative skills is mostly influenced with the creative professional teacher activity. Simultaneously in the process of creative professional teacher working his / her creative skills are revealed, implemented and developed. Under such conditions, it is necessary for teachers to be aware that their own creative professional education activities are in need. Teachers should also analyze their own teaching experience and implement pedagogical experience of other leading experts, taking into account their creative individuality.

Key words: creativeness, intelligence, creativity, convergent thinking, divergent thinking, pedagogical creativeness, teacher training proficiency. 
Вікторія ЗІНЧЕНКО,

orcid.org/0000-0003-3080-4272

кандидат педагогічних наук,

дочент кафедри іноземної філології,

українознавства та соиіально-правових дисииплін

Донецького національного університету економіки і торгівлі імені Михайла Туган-Барановського

(Кривий Ріг, Дніпропетровська область, Украӥна) zinchenko@donпиеt.edu.иа

Світлана РЕВУЦЬКА,

orcid.org/0000-0002-8969-1295

кандидат філологічних наук,

дочент кафедри іноземної філології, українознавства та сочіально-правових дисииплін

Донецького національного університету економіки і торгівлі імені Михайла Туган-Барановського

(Кривий Ріг, Дніпропетровська область, Україна) revutska@donnuet.edu.ua

\title{
КРЕАТИВНІСТЬ ЯК ПСИХОЛОГІЧНИЙ МЕХАНІЗМ ПЕДАГОГІЧНОЇ ТВОРЧОСТІ
}

\begin{abstract}
У статті розглядається креативність як психологічний механізм інженерно-педагогічної творчості. Зазначається, щуо для майбутнього викладача технічних дисциплін правомірно розглядати питання не про ізольований розвиток технічної або педагогічної творчості, а про їх органічне поєднання як основи педагогічної майстерності педагога, щуо певною мірою характеризується креативністю. Надано визначення креативності, дивергентного та конвергентного мислення. Увага акцентується на тому, щуо конвергентне мислення - вид мислення, звичайно асоиійований із вирішенням проблем та інтелектом або будь-яким іншим типом завдань, коли людина працює над отриманням однієї правильної відповіді; цей термін протиставляється дивергентному мисленню, коли людина розробляє нову й оригінальну лінію мислення, яка може містити низку можливих рішень проблеми. Описані базові показники креативності, зокрема швидкість, оригінальність, гнучкість, сприйнятливість, метафоричність тощо. Проаналізовано зв'язок інтелекту та креативності. Кожній професії відповідає нижній допустимий рівень розвитку інтелекту. Особи, які мають рівень інтелекту нижче цього рівня, не можуть опанувати конкретну професію. Якщз рівень інтелекту вищий за нижній допустимий рівень, то прямої залежності між інтелектом і рівнем досягнень немає. Високий рівень розвитку інтелекту зумовлює високий рівень творчих здібностей і навпаки. Люди з високим рівнем інтелекту й низькою креативністю - жертви традиційної системи освіти, яка ставить собі за мету забезпечення учнів максимальною кількістю готових знань. На розвиток творчих можливостей учня впливає творча професійна діяльність викладача. Водночас саме у прочесі творчої професійної діяльності розкриваються творчі можливості педагога, відбуваються їх реалізачія та розвиток. За таких умов виникає необхідність підготовки викладача до усвідомлення рівня власної творчої професійної педагогічної діяльності, формування в нього потреби аналізувати власний педагогічний досвід і впроваджувати педагогічний досвід інших фахівиів з урахуванням своєї творчої індивідуальності.
\end{abstract}

Ключові слова: креативність, інтелект, творча діяльність, конвергентне мислення, дивергентне мислення, інженерно-педагогічна творчість, педагогічна майстерність.

Introduction. The main theoretical aspects of pedagogical activities have been formulated in Soviet pedagogics (G. Batyshev, V. Bezrukov, A. Zeyer, A. Kovalenko, N. Kuzmina, A. Seyteshev etc.). New aspects of engineering activities in the national science are represented in research works of I. Bender, N. Bryukhanov, I. Kankovskyy, A. Kovalenko, M. Lazaryev, V. Lobunets, N. Nychkalo and others. In Ukraine there are few universities that train specialists in "Professional Education" providing qualification of "Engineer and teacher" (Kryvyi Rih National University in Kryvyi Rih city, Podolsky State Agricultural and Technical University in Kamenets-Podolskyi city, Ukrainian Engineering and Pedagogical Academy in Kharkiv).
Formulation of the problem. Specific negative feature of training technical subject teachers after their university graduation is the lack of essential pedagogic knowledge and skills, practical experience and, consequently, the lack of formed education proficiency. Promising way out to overcome this problem is to find approaches of forming the foundations of the pedagogical skills among the teachers of technical subjects. These skills are considered as a psychological and pedagogical education complex, based on the integration of the two activities such as engineering and teaching. The basis of pedagogical skills is provided by means of creativeness. The peculiarities of teaching technical subject make teachers to focus on searching the ways to combine engineering 
creativeness and educational work. Future teachers of technical subjects should reasonably consider not only isolated technical or pedagogical creativeness development, but also their organic integration as the bases of teacher training proficiency (Hunko, 2016).

Research analysis. Investigating the stages and phases of creative thinking was initiated by the French psychologist and teacher, member of the French Academy T. Ribot and British psychologist J. Wallace. In terms of psychology works creativity is studied as an important characteristic of the creative thinking process. This paper aims to consider creativity as a psychological means of pedagogical creativeness.

The purpose of the article. The aim of the article is to consider creativity as a psychological mechanism of engineering and pedagogical creativity.

Presenting main material. The interpretation of the term "creativity". Creativity is a number of creative and innovative activities. This new term outlines "individual creativity, which is characterized by the ability to produce fundamentally new ideas, being an independent factor and the component of a talent structure" (Pavliuk, 2016). Earlier it was used as the definition of "creative skills", but later it was replaced by the borrowing from English "creativity", "creative". In Russian, according to Professor I. Miloslavskyi, the term "creative" indicates creativeness that "not only puts forward ideas, but also brings them to concrete practical results. In the same time the word combination "creative skills" remains with its original value, which does not distinguish productive and non-productive ineffectual activities" (Myloslavskyi, 1978).

The term "creativity" is mostly applied in psychological researches studying the creative person. In psychology, this definition was introduced in 1960's and meant the ability of quick and unconventional intellectual problem solving. It is believed that the more creative features the person obtains, the greater success in creative activity he / she can achieve.

Basic indicators of creativity. Among the main characteristics of creativity psychologists distinguish the following: originality, semantic flexibility, figurative and adaptive flexibility, semantic spontaneous flexibility (J. Guilford); ability to sharp weak point perception, knowledge gaps and insufficient elements disharmony identification (E. Torrens).

R. Pavelko singles out such creativity indicators as: 1) speed (it is the number of ideas that a person is able to produce per time unit); 2) originality (the uncommonness of ideas, which is the measure differing the ideas from accepted standards); 3) flexibility (easy transition from one idea to another); 4) sensitivity (sensitivity to details, nuances, paradoxes);
5) metaphor (the ability to transfer properties of one object (phenomenon) to another based on common characteristics of compared objects).

There is a certain interrelation between creativity and such personality traits as the tendency of self-actualization, speech speed, impulsive, independent judgments, originality, catholicity etc. (psychologists, the founders of humanistic psychology C. Rogers, A. Maslow).

Test method groups investigating creativity. In order to make a diagnostic of creative personality traits the researcher uses special questionnaires. The questions are built to allow analyzing individual creative skills, his / her communication skills, the way of acting etc. Methods of creativity diagnosis can be classified on the basis of such criterion as "the time limitation of investigated individual". There are three groups of test methods: 1) methods regulating the time activity of the investigated individual (British scientist and psychologist H. Eysenck tests); 2) methods, which less regulate the time activities of the investigated individual (creativity tests, offered by Russian psychologist Ya. Ponomarev); 3) methods, in which individual activities are not regulated in terms of time (tests by E. Torrens and D. Gilford that distinguish the concept of intelligence and creativity, considering creativity as divergent thinking).

Convergent and divergent types of thinking. American psychologist J. Guilford stated the existence of two types of thinking: convergent and divergent.

According to R. Pavelkiv definition, convergent thinking is a type of thinking which seeks to achieve a single correct answer. It is based on knowledge. Veracity criterion of such thinking is set from outside. The main mechanism of this type is logical operations (analysis, synthesis).

Convergent thinking is based on precise strategies of using pre-learned algorithms for solving a particular problem. In other words there is already given instruction of sequent steps and elementary content operations to deal with this problem (Kondakov, 2007).

M. Korduell defies convergent thinking and interprets it as a kind of thinking usually associated with intelligence and problem solving, when a person is working on getting the only correct answer. The term is opposed with divergent thinking, when a person develops a new and original way of thinking that may contain a number of possible problem solutions (Korduell, 2000: 140).

Divergent thinking is connected with problem solving by means of variety innovative original solutions. It implies the existence of multiple correct answers. Divergent thinking is considered as a basis of creativity. Divergent thinking is a way of thinking 
that is characterized by speed, flexibility and originality. There are the following evaluation criteria: speed of solving education problems, thought flexibility and originality (Prykhodko, 2012).

Divergent thinking suggests going in different directions. Such way of thinking provides the plurality of equally correct problem solutions. This type of thinking is based on intuition. Its main criterion is originality. Its psychological mechanism is related to association phase and emotional factors, implemented at the unconscious level. The main characteristic of divergent thinking is creativity. It is the ability to generate new and unusual ideas. Creativity to a certain extent is common to everybody.

Methods of divergent thinking diagnosis. To diagnose imagination and divergent thinking different tasks are used. One of them is a subtest consisting of sums (a certain number of tasks or puzzles is given to solve in a certain period of time, such as 20 arithmetical problems for 10 minutes).

Divergent thinking investigations apply D. Wexler labyrinths based on finding the differences between words, developing drawings of various designs; answering paradoxical questions etc. For instance, "Classification" test. The idea of this test is the following: words "arrow, bee, fish, boat, crocodile, kite, sparrow" should be divided into groups by selecting as many classes as possible. The results are evaluated according to such criteria as: simplicity, flexibility and originality. For example, the contestant distinguishes these words in the following way: crocodile, kite, sparrow, fish, bee - animals; kite, sparrow birds; kite, sparrow, arrow, bee - flying objects; fish, boat, crocodile - swimming objects; bee, fish, kite, sparrow - living beings. These results are evaluated as high ones: simplicity -5 points, flexibility -5 , originality - 5 (Sysoieva, 2006: 270).

To develop divergent thinking "Businessman" game can be offered. This game has the following way of acting: students are divided into 3 groups, each group contains two subgroups. The first one creates tasks that are similar to the teacher's data and the other one solves them and vice versa (Sysoieva, 2006: 216).

Intelligence and creativity interrelation. Studying period in person's development is the leading time of active education and cognitive activities and the most favorable period in forming various mental functions and young person intellectual development. The famous Soviet psychologist S. Rubinstein considered individual intellect as "reasonable behavior". S. Goncharenko defies intelligence as a set of mental abilities. Among them one can enumerate the ability to navigate, adequately reflect and transform the surrounding environment, think, learn, explore the world and study social experiences, solve tasks and make decisions, act wisely, predict (Honcharenko, 1997). In general, according to Piaget, intelligence is the manifestation of the universal adaptability in achieving the "balance" between the individual and the environment (Pyazhe, 1969).

The basis of human intelligence is represented with the ability to distinguish essential characteristics of the situation and adjust individual behavior according to them. In this sense, the structure of intelligence contains two components which illustrate intelligence as the ability to investigate the surrounding world and as the means of regulating behavior based on acquired knowledge. Intelligence is one of the most complex and multi-level structure of the individual psychic.

The structure of the intelligence system includes cognitive processes. Due to them a person perceives the surrounding world. T. Turkot describes information reception and processing in the following way: stimuli acting on the sense perception consequently create nerve impulses that go along nerve paths and reach the brain. Coming there nerve impulses are processed creating some feelings or a complete image of the object, which is compared to a standard one kept in the individual memory. The result of this comparison is the recognition of the object, and then after the mental comparison of current information and previous experience using the means of mental activities the concept of the object is created. Attention should be focused on the reception and understanding of this information. One should bear in mind while the perceptions reflect external single properties and attributes of the studied objects and phenomena, their concepts reveal their deep essence, internal causes and consequences.

Along with intelligence the British and American psychology of the mid 50-ies started to apply the term "creativity". This definition was involved into the scientific use to characterize human cognitive activity due to data proving the absence of interrelation between the results of conventional intelligence tests and successful problem solving. Creativity defies the capability to create new knowledge, i.e. the ability of creativeness. Creativity is an ability that characterizes the individual to create new concepts and create new skills. It is the ability of creativeness. The creativity concept is studied, apart from intelligence and deeply interrelated with individual creative achievements.

J. Guildford was the first scientist who contrasted intelligence and creativity. He relied on his own theory of two types of thinking: convergent and divergent. Convergent thinking is aimed at analyzing all the available ways of solving the problem in order to select a single correct one. Convergent thinking is the basis of 
intelligence. Divergent thinking is a way of thinking, "that goes in many directions at once", it is intended to generate several different options for solving the problem. Divergent thinking is the basis of creativity.

There is no direct interdependence among indicators of convergent and divergent thinking. Convergent thinking is diagnosed using intelligence tests that demonstrate the IQ result (IQ talent).

P. Torrens and J. Guilford researching reveals high positive correlation between the IQ level and the level of creativity. The higher IQ is, the greater the probability that the contestant will have better results in creativity tests. However people with highly developed intelligence can happen to get a low creativity index. P. Torrens offered the theory of intelligent threshold. For instance, when the IQ is about $115-120$ points or lower than intelligence and creativity form a single factor. If the IQ result is over than 120 points creativity and intelligence are independent factors. In other words, there are no creative people with low intelligence, but there are intellectuals with low creativity. People with a high IQ and low creativity are the victims of the traditional education system aimed to provide students with the maximum of ready made knowledge. As Greek philosopher Heraclitus of Ephesus pre-Socratics stated "Much knowledge does not provide intelligence". People with high IQ and creativity are intensively investigated by psychologists in the context of talent consideration.

P. Torrens and J. Guilford studies coincide with D. Perkins' data, which emphasize that each profession corresponds to the lower permissible level of intelligence. Individuals who have IQ below this level can not master a particular profession. If IQ is higher than this level, there is a direct correlation between intelligence and achievement level. The higher level of intelligence creates the higher levels of creative abilities and vice versa (D. Wexler, R. Weisberg, G. Eysenck, R. Stenberg et al.).

D. Wexler, H. Eysenck and R. Stenberg consider intelligence and creativity as the only human capacity of higher level. V. Druzhynin describes this comparison as "a reduction of creativity to intelligence". This assumption means that creativity is not just the only ability, but originally the intelligence derivative. High intelligence supposes high creativity. Low intelligence causes low creativeness ability. H. Eysenck says that there is no need to distinguish creativity as a special capacity. The capacity for any type of creativity (scientific, artistic) is provided primarily by high level of general intelligence.

The concept of creativity and intelligence interrelation developed by $\mathrm{M}$. Wollach and N. Kogan is based on test investigations. Thus, according to
American psychologists M. Wollach and N. Kogan, there is no use of applying strict time limits, competition atmosphere and the single correct answer criteria. Creativity abilities should be investigated and tested preferably in normal situations with free access to additional information while performing the tasks. During creativity testing, contestants are provided with enough time to solve the problem and formulate their answers to the questions. Testing is carried out in a game way, but a competition between the groups is minimal, the scientist receives any response. Under these conditions the correlation between creativity and intelligence test is close to zero.

A. Voronin, conducting experiments in terms of psychology abilities laboratory in the Psychology Institute of the Russian Academy of Sciences, achieves similar results: the factors of intelligence and creativity are independent. Ukrainian psychologist E. Hryhorenko has discovered in his studies complimentarity of creativity and intelligence among the contestants while solving cognitive tasks.

There are at least three main approaches to the problem of creativity and intelligence interrelation. Intellectual talent acts as a necessary but insufficient condition for creativity development. Among the primarily important characteristics determining creativity are motivation, values, personal qualities (A. Tannenbaum, A. Oloh, D. Epiphany, A. Maslow and others). Creativity (creative ability) is an autonomous factor, independent of intelligence, or it has little correlation (J. Guildford, C. Taylor, G. Gruber et al.).

M. Wollach and N. Kogan approach allows differently deal with the problem of creativity and intelligence interrelation. The theoretical basis of M. Wollach and N. Kogan concept outlines typological groups of students with different levels of intelligence and creativity. These groups differ in the way of adjusting to different environmental conditions and solving problems. The data can be used by high school teachers for taking into account the features of students with different intelligence and creativity levels.

Creative teaching. Creative teaching is defined as education activities, characterized by similar properties as the creative process (Kolesnyk). On contrary to the personal approach of investigating the creativeness among students, the study of creativity among teachers focuses on the activity approach. Creative professional teacher activity is considered as the leading factor that influences the development of student creative abilities of and ensures their effectiveness. At the same time actually in the process of creative professional work teacher's creative abilities are revealed, implemented and developed. Under such conditions, it is necessary to train a teacher who can 
be aware of his / her own creative professional education activities. Moreover, it is essential for a teacher to analyze his / her own teaching experience and pedagogical experience, implement the experience of other experts, taking into account his /her own creative individuality.

Creative teaching activities are researching activities. The teacher, who acts creatively, is guided with the pedagogic achievements. The teacher enriches pedagogical theory and reveals patterns of education process. He determines the ways of its improvement and predicts its performance. The creative teacher is a creative person with a highly developed level of motivation, traits and creative skills that contribute to successful creative education activities. As a result of special training and continuous improvement, such a teacher acquires knowledge and skills of education work and as well as obtains the skills of forming creative student personality in the education process.

The ability of a creative teacher to creative teaching is characterized not only with the high level of teaching creativity. According to contemporary requirements creative teaching includes not only highly qualified subject teaching level, but also acquired psychological and pedagogical knowledge and skills that ensure the efficiency of teacher interaction with the students within the development of their creative capabilities in terms of educational process (Plakhotniuk, 2012).

Conclusions. While training future teachers of technical subjects it is legitimately to consider both technical development and teaching work in their combination as organic bases of teacher peda- gogical skill, to some extent characterized by creativity. Creativity is the psychological mechanism of pedagogical creativeness. The basic creativity features are the speed, originality, flexibility, sensitivity, metaphoricity. Convergent thinking is the kind of thinking usually associated with problem solving and intelligence, or any other type of problem solving connected with getting the only one correct answer. This term is opposed with divergent thinking, when a person develops a new and original way of thinking that may contain a number of possible problem solutions. Creativity is investigated in terms of intelligence levels. Every profession corresponds to the lower permissible intelligence level. Individuals who have IQ below this level can not master a particular profession.

There are different approaches to the problem of creativity and intelligence interrelation: intellectual talent serves as a necessary but insufficient condition for creativity. While the most important role in the determining creative behaviors belongs to motivation, values, personal qualities. Creativity (creative ability) is an autonomous factor, independent of intelligence, or it has little correlation. The development of student creative capacities is strongly influenced by teacher professional creative activity. The creative teacher is a creative person with a highly developed level of motivation, traits and creative skills that contribute to successful creative education activities. As a result of special training and continuous improvement, such a teacher acquires knowledge and skills of educational work and obtains the skills of forming creative student personality in the education process.

\section{BIBLIOGRAPHY}

1. Гончаренко С. Український педагогічний словник. Київ : Либідь, 1997. 376 с. URL: http://hum.edu-lib.net/ szbrannoe/goncharenko-s-u-ukrayinskiy-pedagogichniy-slovnik-onlayn.

2. Гунько Н. Інженерно-педагогічна творчість як основа педагогічної майстерності викладача технічних дисциплін. URL: http://nauka.zinet.info/28/Gunko.php.

3. Жицька С. Підготовка курсантів вищих військових навчальних закладів до професійно-комунікативної діяльності за допомогою метода комунікативних завдань. Новітня освіта. 2014. № 1. С. 13-20.

4. Колесник Н. Організація художньо-технічної творчості учнів у позанавчальний час. URL: https://www.researchgate.net/publication/40637459_Organizacia_hudozno-tehnicnoi_tvorcosti_ucniv_pocatkovih_ klasiv_u_pozanavcalnij_cas.

5. Кондаков В. Психология : иллюстрированный словарь. 2-е изд., доп. и перераб. Санкт-Петербург : ПраймЕврознак, 2007. 783 c. URL: http://psychologiya.com.ua/psixologicheskij-slovar.html.

6. Кордуэлл М. Психология. А - Я : словарь-справочник. Пер. с англ. К. Ткаченко. Москва : ФАИР-ПРЕСС, 2000. $448 \mathrm{c}$.

7. Милославский И. Креативный или творческий? Москва : Знание, 1978. 38 с.

8. Палій А. Диференціальна психологія. URL: http://westudents.com.ua/glavy/76593-kontseptsya-vzamozvyazkukreativnost-ta-ntelektu-m-vollaha-n-kogana.html.

9. Пиаже Ж. Избранные психологические труды. Психология интеллекта. Москва : Просвещение, 1969. 659 с.

10. Плахотнюк Ю. Творча особистість у педагогіці. URL: https://videouroki.net/razrabotki/tvorcha-osobistist-upedagogitsi.html.

11. Приходько Ю. Психологічний словник-довідник. Київ : Каравела, 2012. 328 c. URL: http://www.psyh.kiev.ua.

12. Сисоєва С. Основи педагогічної творчості. Київ : Міленіум, 2006. 344 с. 


\section{REFERENCES}

1. Honcharenko S. U. Ukrainskyi pedahohichnyi slovnyk [Ukrainian pedagogical dictionary]. K. : Lybid, 1997. 376 p. URL: http://hum.edu-lib.net/szbrannoe/goncharenko-s-u-ukrayinskiy-pedagogichniy-slovnik-onlayn [in Ukranian].

2. Hunko N. A. Inzhenerno-pedahohichna tvorchist yak osnova pedahohichnoi maisternosti vykladacha tekhnichnykh dystsyplin [Engineering and pedagogical creativity as a basis of pedagogical skill of the teacher of technical disciplines]. URL: http://nauka.zinet.info/28/Gunko.php [in Ukranian].

3. Zhytska S. A. Pidhotovka kursantiv vyshchykh viiskovykh navchalnykh zakladiv do profesiino-komunikatyvnoi diialnosti za dopomohoiu metoda komunikatyvnykh zavdan [Preparation of cadets of higher military educational institutions for professional and communicative activity by means of a method of communicative tasks]. Novitnia osvita. 2014 . № 1 . pp. 13-20 [in Ukranian].

4. Kolesnyk N. Ye. Orhanizatsiia khudozhno-tekhnichnoi tvorchosti uchniv u pozanavchalnyi chas [Organization of artistic and technical creativity of students in extracurricular time]. URL: https://www.researchgate.net/publication/40637459 Organizacia_hudozno-tehnicnoi_tvorcosti_ucniv_pocatkovih_klasiv_u_pozanavcalnij_cas [in Ukranian].

5. Kondākov V. M. Psiholōgiya : illyüstrirovannyiy slovar [Psychology : An Illustrated Dictionary]. 2-e izd., dop. i pererab. SPb. : Praym-Evroznak, 2007. 783 p. URL: http://psychologiya.com.ua/psixologicheskij-slovar.html [in Russian].

6. Korduell M. Psihologiya. A - Ya : slovar-spravochnik [Psychology. A - Z : reference dictionary] / per. s angl. K. S. Tkachenko. M. : FAIR-PRESS, 2000. 448 p. [in Russian].

7. Miloslavskiy I. Kreativnyiy ili tvorcheskiy? [Creative or Creative?]. M. : Znanie, 1978. 38 p. [in Russian].

8. Palii A. A. Dyferentsialna psykholohiia [Differential psychology]. URL: http://westudents.com.ua/glavy/76593kontseptsya-vzamozvyazku-kreativnost-ta-ntelektu-m-vollaha-n-kogana.html [in Ukranian].

9. Piazhe Zh. Izbrannyie psihologicheskie trudyi. Psihologiya intellekta [Selected psychological works. The psychology of intelligence]. M. : Prosveschenie, 1969. 659 p. [in Russian].

10. Plakhotniuk Yu. I. Tvorcha osobystist u pedahohitsi [Creative personality in pedagogy]. URL: https://videouroki.net/ razrabotki/tvorcha-osobistist-u-pedagogitsi.html [in Ukranian].

11. Prykhodko Yu. O. Psykholohichnyi slovnyk-dovidnyk [Psychological dictionary-reference book]. K : Karavela, 2012. 328 p. URL: http://www.psyh.kiev.ua [in Ukranian].

12. Sysoieva S. O. Osnovy pedahohichnoi tvorchosti [Fundamentals of pedagogical creativity]. K. : Milenium, 2006.344 p. [in Ukranian]. 